\title{
Allelopathy of Sorghum Residues on Weed Establishment Is Affected by Hybrid, Phenolic Acid Contents and Environment
}

\author{
Robert John Kremer, Timothy Martin Reinbott \\ School of Natural Resources and Division of Plant Sciences, University of Missouri, Columbia, USA
}

Email address:

kremerr@missouri.edu(R.J. Kremer)

\section{To cite this article:}

Robert John Kremer, Timothy Martin Reinbott. Allelopathy of Sorghum Residues on Weed Establishment Is Affected by Hybrid, Phenolic Acid Contents and Environment. Journal of Plant Sciences. Special Issue: Use of Allelopathy in Agriculture: New Futures, Challenges and Future Prospects. Vol. 9, No. 1, 2021, pp. 25-31. doi: 10.11648/j.jps.20210901.14

Received: January 4, 2021; Accepted: March 5, 2021; Published: March 13, 2021

\begin{abstract}
Sorghum species are well known for allelopathic potential toward weeds and other crops. Sorghum above-ground residues mediate allelopathic activity through production and release of many allelochemicals including phenolic acids. Information is limited on selection of grain sorghum hybrids with high allelopathic potential and assessment of sorghum residue phenolic activity in soil under field conditions. This study was carried out to investigate several grain sorghum hybrids for allelopathic potential for suppressing weed growth in the field in the subsequent growing season; and to investigate the involvement of phenolic substances released into soil on the establishment of weeds. The weed seedbank was affected by environmental conditions that led to different weed densities subjected to suppression by residues in soil. Differential allelopathy was identified among the sorghum hybrids suggesting that improved selection may increase production and release of allelochemicals in new hybrids to control weeds inexpensively, easily, and environmentally friendly. Tillage type (till vs no-till) had variable effects on weed suppression. Soil type, environment, sorghum hybrid traits and cultural practices complicate the use of allelopathy in weed control and benefits gained from this potentially environment friendly weed control practice. Well-planned management will be required to successfully integrate allelopathic crops into sustainable crop production.
\end{abstract}

Keywords: Allelochemicals, Cover Crops, Soil Phenolic Carbon, Tillage, Weed Density, Weed Seedbank

\section{Introduction}

Allelopathy refers to direct or indirect harmful or beneficial effects of one plant on another mediated by release of organic chemicals (allelochemicals) into the environment. Allelochemicals can be continuously released by the allelopathic plants into their immediate environment as water leachates, root exudates in soil, volatiles in the air, and as leachates or products of plant residue decomposition [1]. Many crop or cover crop vegetative residues suppress weed growth and sometimes the subsequent crop in a crop rotation through allelochemicals released from roots or vegetative residues. All plant structures including roots, stems, leaves, flowers, fruits, and seeds are capable of releasing chemicals into the environment.

Sorghum species are well known for allelopathic potential toward weeds and other crops [2]. Einhellig \& Rasmussen [3] reported that sorghum amended soils decreased pigweed (Amaranthus retroflexus L.) and morningglory (Ipomoea spp.) emergence. Sorghum residues incorporated into soil at two to six tons/ha reduced incidence of weeds and increased yield of irrigated wheat in a semiarid environment [4]. Residues of Sorghum species release a number of allelochemicals including sorgleone, cyanogenic glycosides, and phenolic compounds $[2,5,6,7]$. Several varieties or hybrids of sorghum have been screened for weed-suppressive ability and correlated with allelochemical content of their residues. However, allelopathic screening has primarily focused on sorgoleone production and concentration [2]; little research is available on screening for phenolic-based compounds as allelochemicals. Ben-Hammouda et al. [5, 6], studying allelopathy of grain sorghum [(Sorghum bicolor L. Moench)] toward winter wheat (Triticum aestivum L.) in a cropping sequence, noted differential effects dependent on sorghum 
hybrid and that phenolic acid content of sorghum residues contributed to the allelochemical effects on wheat growth. The phenolic acids identified included p-hydroxybenzoate, vanillic acid, syringic acid, ferulic acid and p-coumaric acid and contributed to the allelopathic activity of sorghum residues that suppressed wheat growth when planted after grain sorghum [6].

Einhellig and Rasmussen [3] showed that a grain sorghum crop significantly inhibits late weed growth by releasing phenolic compounds. They suggested using a sorghum crop for weed management in order to reduce reliance on herbicides. Phenolic acids are released into soils by root exudation, decomposing vegetative residues, and leaching from plant parts of the residues [8] and likely contact the weed seedbank. Sorghum vegetative residues decompose slowly resulting in a persistent ground cover and providing good physical and allelopathic weed suppression, particularly on small-seeded annual broadleaf weeds [2]. Overall allelopathic effects depend on quantity and extent of degradation of the phenolic compounds and interactions among the phenolics with soil components.

Modes of action of phenolic acids leading to detrimental effects on plant biological processes include disruption of cell membrane integrity and cell elongation, alterations in biosynthesis of critical compounds such as proteins and lipids, interference with growth regulator function, altered key enzyme functions, interference with respiration, inhibition of photosynthesis and related processes, and interfering with nutrient uptake [9]. The mechanisms of action mediated by phenolic acids include uptake by solubilization into cell membranes leading to failure of cells to maintain proper mineral balance and water status and disruption of electron flow that uncouples phosphorylation and disrupts photosynthesis [9]. Root mitosis and cell division is also suppressed and result in poor overall growth.

Because growth suppression of wheat was partly attributed to allelopathic effects of specific sorghum hybrids and mediated by phenolic acids identified as important allelochemicals within the residues, research was conducted to screen hybrids for weed-suppressing residues and relate the allelopathic activity to phenolic compounds released into soil by interfering with weeds emerging from the seedbank. The potential for allelopathic crop varieties is a promising strategy for weed management yet development of crop cultivars with strong allelopathic potential is only in early stages even though research in this area has increased international attention [10]. Identification of cultivars with high allelopathic potential and introducing such characteristics into modern cultivars might restore traits inadvertently lost during breeding programs focused on higher productivity. Limited research in cucumber (Cucumis sativus L.), rice (Oryza sativa L.), oats (Avena sativa L.), wheat and sunflower (Helianthus annua L.) has shown considerable variation in allelopathic activity, with some accessions strongly inhibiting growth of certain weed species $[10,11]$. Strategies used for screening cover crops such as choice of variety, planting date, seeding rate, residue management, tillage system, and time between residue deposition and succession crop planting [12] could be applied to screening sorghum hybrids for allelopathic potential in weed suppression. A recent meta-analysis review of literature revealed that various sorghum species used as cover crops provided very high suppression based on weed growth response to sorghum biomass remaining on or incorporated in soil [12].

This study was carried out to investigate several grain sorghum hybrids for allelopathic potential of residues for suppressing weed growth in the field in the subsequent growing season; and to investigate the involvement of phenolic substances released into soil on the establishment of weeds. Findings from the research should help in developing improved management practices to exploit allelopathic effects of grain sorghum when included as part of a crop rotation or as a summer cover crop.

\section{Materials and Methods}

\subsection{Site Description and Experimental Design}

Field studies were conducted at the University of Missouri Bradford Research Center, located in Boone County, $8 \mathrm{~km}$ east of Columbia, Missouri, U.S.A. The soil was a Mexico silt loam (fine, smectitic, mesic Vertic Epiaqualfs) with $2.5 \%$ organic matter, $\mathrm{pH} 5.55,30 \mathrm{~g} / \mathrm{kg} \mathrm{P}, 100 \mathrm{~g} / \mathrm{kg} \mathrm{K}, 1520 \mathrm{~g} / \mathrm{kg} \mathrm{Ca}$ and $170 \mathrm{~g} / \mathrm{kg} \mathrm{Mg}$. Sorghum hybrids were planted at 258,000 seeds $\mathrm{ha}^{-1}$ in 76-cm rows in June 1999 and 2000. Plots were $6.1 \mathrm{~m}$ long by 8 rows wide. Fertilizer was applied based on soil test recommendations for a yield goal of $6270 \mathrm{~kg} / \mathrm{ha}$. Sorghum was planted in a split-plot arrangement of a randomized complete block design with six replications. The main plot treatments were sorghum hybrids and one control (residues removed). Eight grain sorghum hybrids were grown to evaluate allelopathic potential and included NC7847, Cargill 737, MFA GS-10, N9212, Asgrow A570, Dekalb 44C, Pioneer 8500 and Pioneer 84G62. The subplot treatments were tillage or residue management (conventional - disked vs no-till).

\subsection{Experimental Procedures and Data Collection}

Emerged weeds were counted within a $0.1 \mathrm{~m}^{2}$ quadrat placed in each plot in June 2000 and 2001. Weeds were separated into grass, broadleaf and total classifications. Dominant weed species were identified and recorded for grasses and broadleaf species. Grass, broadleaf and total weeds were expressed on a $\mathrm{m}^{2}$ basis.

Soil samples were collected simultaneously with weed density determinations. Five soil cores $(3.5-\mathrm{cm}$ diam) from each plot were obtained from 0 to $7.6 \mathrm{~cm}$ depth, bulked and sieved $(<4 \mathrm{~mm})$ on site and transported to the laboratory. Soil phenolic $\mathrm{C}$ was determined following Ohno et al. [13] extracting $10 \mathrm{~g}$ dry weight equivalent of soil with $40 \mathrm{ml}$ of $\mathrm{pH}$ 7.0, 0.25M sodium citrate and shaken for $2.5 \mathrm{~h}$. Citrate extract samples were centrifuged for $15 \mathrm{~min}$ at $1000 \mathrm{x}$ g and passed through $0.2 \mu \mathrm{m}$ nitrocellulose membrane filters under vacuum. Phenolic $\mathrm{C}$ was analyzed using the Folin-Ciocalteu method 
wherein $0.75 \mathrm{ml}$ of $1.9 \mathrm{M}$ Folin-Ciocalteu reagent (Sigma) were added to $5 \mathrm{ml}$ of extract or standard phenolic solution and absorbance read at $750 \mathrm{~nm}$ after allowing to develop the blue chromophore in the dark for $60 \mathrm{~min}$. Ferulic acid was used to derive the standard curve and concentrations expressed in ferulic acid equivalent units.

Analysis of variance was conducted using the GLM procedure of SAS (SAS Inst., Cary, NC). Mean separation was evaluated using Fishers protected LSD test at $(p<0.05)$ for significance of main effects and all interactions. Regression and Pearson correlation analysis of soil phenolic $\mathrm{C}$ on weed densities were conducted using the CORR procedure of SAS.

\section{Results and Discussion}

Sampling year significantly $(p<0.01)$ influenced weed density, soil phenolic C content, and extent of weed suppression by grain sorghum hybrids. Weed densities for both grasses and broadleaf as well as total weed density increased greatly between the 2000 and 2001 growing seasons when soils were sampled. Variable weather conditions likely contributed to differences in these parameters measured between the 2000 and 2001 sampling dates. The growing season (April to October) of 1999 in central Missouri was considerably drier with cumulative precipitation of $430 \mathrm{~mm}$ relative to the a 30-year average of $700 \mathrm{~mm}$ and the low precipitation trend carried over into late spring to early summer of 2000 when the 1999 sorghum residue plots were sampled. Seasonal rainfall returned to normal levels in spring and summer of 2001 (710 mm growing season cumulative precipitation), which likely stimulated an increase in weed densities by more than $50 \%$, most prominently the grass cohort. Tillage influenced weed suppression by nearly all hybrids and increased soil phenolic $\mathrm{C}$ released from sorghum residues. Sorghum hybrid residues differentially affected weeds during both years regardless of tillage.

Grasses were dominated by giant foxtail (Setaria faberi Herrm.) and major broadleaf weeds included waterhemp and pigweed species (Amaranthus spp.), morningglory species (Ipomoea spp.), common ragweed (Ambrosia artemisiifolia L.) and velvetleaf (Abutilon theophrasti Medik.). Grass weed densities were significantly higher $(\mathrm{p}<0.001)$, from 5 to 50 times greater, for all hybrids and the non-residue control in both tillage treatments in 2001 (Table 1). Broadleaf weeds did not follow the increased trend of grasses and densities in most hybrid residue treatments were similar or lower in 2001 (Table 2). Total weed densities were three to twelve times higher in 2001, which reflected the drastic increases in grass species (Table 3). In 2000 grass densities decreased by 92 to $38 \%$ by sorghum residues relative to the non-residue control under conventional tillage and 79 to $96 \%$ under no-till (Table 1). In 2001 , under higher grass pressure, decreases in density ranged from $89 \%$ to $52 \%$ under sorghum residues in conventional tillage and from $87 \%$ to $46 \%$ in no-till. Sorghum hybrids with consistent high suppression in both years and both tillage treatments were NC7B47, MFA GS-10 and N9212. Trends for growth suppression of broadleaf weeds were similar to grasses in both years and tillage practices by the same sorghum hybrids with addition of Pioneer 8500 (Table 2). Trends for growth suppression on a total weed basis were similar to grasses and broadleaf suppression and consistent high suppression among the same sorghum hybrids (Table 3). No consistent effects of tillage on growth suppression by sorghum hybrids across years were detected.

Table 1. Density of grass weeds affected by residues of sorghum hybrids under conventional and no-tillage during 2000 and 2001.

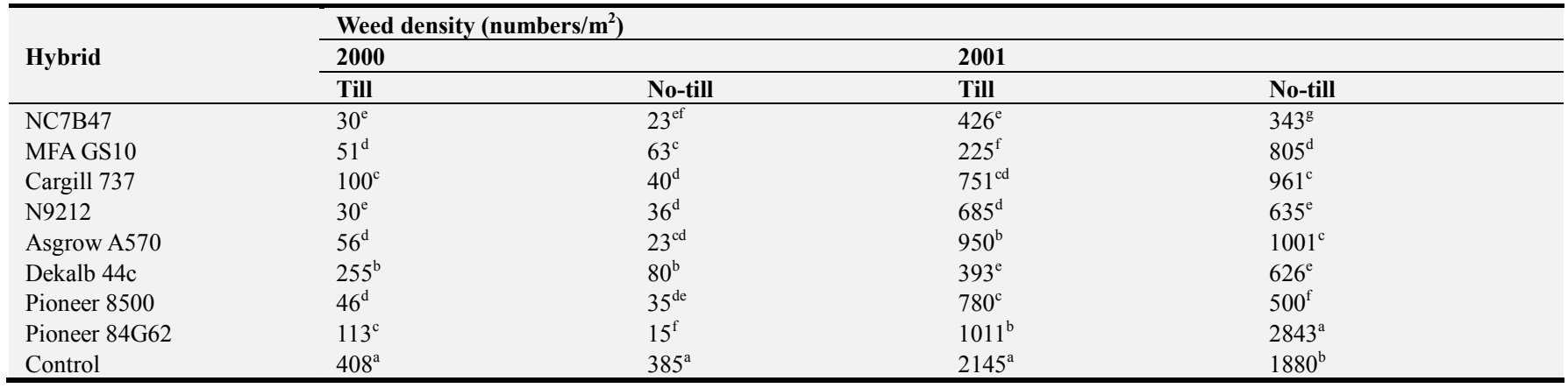

Means with the same letters within years are not significant at $\mathrm{p}<0.05$

Sorghum hybrids differed in allelopathic activity toward weed seedling densities. However, significant interactions suggest that allelopathy was also affected by the annual variation in precipitation and soil moisture content, leading to vast differences in grass and total weed densities $[8,14,15,16]$.

Our results suggest that sorghum residues produce consistent allelopathic activity toward germinating and seedling weeds under contrasting environmental conditions despite the flush in grass weed emergence in 2001. Giant foxtail in the soil seedbank likely became dormant in early spring of 1999 and 2000 when surface soil temperatures exceeded $16^{\circ} \mathrm{C}$, the threshold temperature for inducing secondary dormancy, resulting in little further germination and low seedling densities [14]. In 2001, the threshold soil temperature did not reach $16^{\circ} \mathrm{C}$ until early to mid-June, which allowed continuous seed germination and seedling emergence into late spring to early summer, resulting in high grass densities. Soil moisture content was also likely more favorable for seed germination in 2001 when surface soils were at 20 to $25 \%$ moisture compared with 13 to $17 \%$ moisture in 2000 .

Seemingly substantial residue cover was provided by sorghum vegetative biomass, ranging from $8.5 \mathrm{t} /$ ha for MFA 
GS-10 to $12 \mathrm{t} /$ ha for Asgrow A570 - an overall hybrid average of $10.7 \mathrm{t} / \mathrm{ha}$ - yet effective control of weeds was not achieved in 2001. The high residue quantities are similar to the high-yielding biomass variants of sorghum species [15] that produced sufficient residue to suppress weeds well into the next cropping season. However, given the magnitude of grass weed densities emerging through the residue treatments in 2001, efficacy of control cannot be considered satisfactory even though the most productive and allelopathic hybrids reduced total weed densities by nearly $90 \%$ (Table 3 ). Other studies investigating weed responses to sorghum residues applied at 3.5 to $7.6 \mathrm{t} / \mathrm{ha}$ also found that inhibitory potential was below herbicide control efficacies $[2,15]$. In contrast, broadleaf weed species were suppressed by sorghum residues similarly in both years (Table 2). This agrees with previous research showing that broadleaf annual weeds are sensitive to various allelochemicals and are suppressed during the year following sorghum cover crop establishment [3]. Our study shows that environmental factors such as precipitation, soil moisture and soil temperature may influence allelopathic crops and their ability to suppress weeds. Soil moisture was also implicated in allelochemical release into soil from rye (Secale cereale L.) biomass in decomposition studies [17]. Most studies evaluating weed suppression by crop plants are conducted at sites with apparent adequate rainfall or with irrigation. An underlying principle for using crops to provide weed suppression is to maximize residue biomass and surface cover, however the effectiveness of this strategy, as we demonstrate here, is subject to environment, soil conditions, crop species or variety and management decisions [11, 12].

Table 2. Density of broadleaf weeds affected by residues of sorghum hybrids under conventional and no-tillage during 2000 and 2001.

\begin{tabular}{|c|c|c|c|c|}
\hline \multirow{3}{*}{ Hybrid } & \multicolumn{4}{|c|}{ Weed density (numbers $/ \mathrm{m}^{2}$ ) } \\
\hline & \multicolumn{2}{|l|}{2000} & \multicolumn{2}{|l|}{2001} \\
\hline & Till & No-till & Till & No-till \\
\hline NC7B47 & $52^{\mathrm{f}}$ & $25^{\mathrm{e}}$ & $27^{\mathrm{c}}$ & $18^{\mathrm{b}}$ \\
\hline MFA GS10 & $76^{\mathrm{e}}$ & $70^{\mathrm{c}}$ & $9^{c}$ & $17^{\mathrm{b}}$ \\
\hline Cargill 737 & $115^{\mathrm{d}}$ & $48^{\mathrm{d}}$ & $24^{\mathrm{c}}$ & $30^{\mathrm{b}}$ \\
\hline N9212 & $110^{\mathrm{d}}$ & $31^{\mathrm{bc}}$ & $110^{\mathrm{b}}$ & $34^{\mathrm{ab}}$ \\
\hline Asgrow A570 & $165^{\mathrm{b}}$ & $58^{\mathrm{cd}}$ & $48^{\mathrm{bc}}$ & $36^{\mathrm{ab}}$ \\
\hline Pioneer 8500 & $55^{\mathrm{f}}$ & $56^{\mathrm{d}}$ & $23^{\mathrm{c}}$ & $26^{\mathrm{b}}$ \\
\hline Pioneer 84G62 & $60^{\mathrm{f}}$ & $33^{\mathrm{e}}$ & $26^{\mathrm{c}}$ & $31^{\mathrm{ab}}$ \\
\hline Control & $273^{\mathrm{a}}$ & $155^{\mathrm{a}}$ & $225^{\mathrm{a}}$ & $93^{\mathrm{a}}$ \\
\hline
\end{tabular}

Means with the same letters within years are not significant at $\mathrm{p}<0.05$

Table 3. Density of total weeds affected by residues of sorghum hybrids under conventional and no-tillage during 2000 and 2001.

\begin{tabular}{|c|c|c|c|c|}
\hline \multirow{3}{*}{ Hybrid } & \multicolumn{4}{|c|}{ Weed density (numbers/m²) } \\
\hline & \multicolumn{2}{|l|}{2000} & \multicolumn{2}{|l|}{2001} \\
\hline & Till & No-till & Till & No-till \\
\hline NC7B47 & $81^{\mathrm{f}}$ & $48^{g}$ & $454^{\mathrm{e}}$ & $362^{g}$ \\
\hline MFA GS10 & $128^{\mathrm{e}}$ & $133^{\mathrm{c}}$ & $234^{\mathrm{f}}$ & $822^{\mathrm{d}}$ \\
\hline Cargill 737 & $215^{\mathrm{c}}$ & $88^{\mathrm{e}}$ & $776^{\mathrm{cd}}$ & $991^{\mathrm{c}}$ \\
\hline N9212 & $140^{\mathrm{e}}$ & $68^{f}$ & $745^{\mathrm{d}}$ & $668^{\mathrm{e}}$ \\
\hline Asgrow A570 & $221^{\mathrm{c}}$ & $82^{\mathrm{e}}$ & $997^{\mathrm{b}}$ & $1035^{\mathrm{c}}$ \\
\hline Pioneer 8500 & $102^{\mathrm{d}}$ & $92^{\text {de }}$ & $803^{\mathrm{c}}$ & $526^{\mathrm{f}}$ \\
\hline Pioneer 84G62 & $173^{d}$ & $48^{\mathrm{g}}$ & $1038^{\mathrm{b}}$ & $2874^{\mathrm{a}}$ \\
\hline Control & $681^{\mathrm{a}}$ & $540^{\mathrm{a}}$ & $2370^{\mathrm{a}}$ & $1973^{\mathrm{b}}$ \\
\hline
\end{tabular}

Means with the same letters within years are not significant at $\mathrm{p}<0.05$

Table 4. Soil phenolic C as affected by residues of sorghum hybrids under conventional and no-tillage during 2000 and 2001.

\begin{tabular}{|c|c|c|c|c|}
\hline \multirow{3}{*}{ Hybrid } & \multicolumn{4}{|c|}{ Soil phenolic C (g/kg soil) } \\
\hline & \multicolumn{2}{|l|}{2000} & \multicolumn{2}{|l|}{2001} \\
\hline & Till & No-till & Till & No-till \\
\hline NC7B47 & $56^{\mathrm{d}}$ & $74^{\mathrm{bc}}$ & $54^{\mathrm{bc}}$ & $43^{\text {bcd }}$ \\
\hline MFA GS10 & $69^{\mathrm{bc}}$ & $78^{\mathrm{ab}}$ & $54^{\mathrm{bc}}$ & $44^{\text {bcd }}$ \\
\hline Cargill 737 & $62^{\text {cd }}$ & $64^{\mathrm{d}}$ & $23^{\mathrm{e}}$ & $53^{\mathrm{a}}$ \\
\hline N9212 & $83^{\mathrm{a}}$ & $71^{\mathrm{bc}}$ & $59^{\mathrm{ab}}$ & $51^{\mathrm{ab}}$ \\
\hline Asgrow A570 & $58^{\mathrm{d}}$ & $70^{\text {cd }}$ & $51^{\mathrm{cd}}$ & $21^{\mathrm{e}}$ \\
\hline Pioneer 8500 & $63^{\mathrm{cd}}$ & $74^{\mathrm{bc}}$ & $62^{\mathrm{a}}$ & $40^{\mathrm{d}}$ \\
\hline Pioneer 84G62 & $64^{\mathrm{cd}}$ & $83^{\mathrm{a}}$ & $51^{\mathrm{cd}}$ & $46^{\mathrm{abc}}$ \\
\hline Control & $46^{\mathrm{e}}$ & $49^{\mathrm{e}}$ & $28^{\mathrm{e}}$ & $30^{\mathrm{e}}$ \\
\hline
\end{tabular}

Means with the same letters within years are not significant at $\mathrm{p}<0.05$

NOTE: Soil phenolic $\mathrm{C}$ is expressed as $\mathrm{g}$ ferulic acid equivalents 
Soil phenolic $\mathrm{C}$ content was strongly associated with extent of weed suppression by the most allelopathic hybrids within both years and tillage (Table 4). Extended weed suppression by sorghum residues remaining from the previous season is attributed to the innate persistence of grass residues, which deteriorate slower in the field [12]. Sorghum residues may consistently provide over $90 \%$ weed suppression, relative to bare ground controls, compared to single species broadleaf cover crops that range from 32 to $89 \%$ weed suppression [12].

Biochemical analysis revealed the presence of higher total soil phenolics in sorghum amended field plots than control plots (Table 4), which coincided with higher weed suppression by residues of those hybrids associated with high soil phenolic content. Previous studies related maximum quantities of phenolics with maximum suppressive activity against weeds under field conditions, which explain the activity of phytotoxins on weed suppression [16]. Based on previous work with allelopathic interactions with wheat $[5,6]$ using a selection of those hybrids in the present study, the significant reduction in weed density and growth by sorghum residues are primarily due to the release of allelochemicals from the residues by leaching, during decomposition, and by release from roots remaining in soil [1]. The selected sorghum hybrids produced p-coumaric acid, vanillic acid, syringic acid, ferulic acid and p-hydroxybenzoate inhibitory to wheat growth [6] that likely also inhibited weed growth. A previous study reported that these phenolic acids released from sorghum residues increased soil phenolic content by up to $185 \%$ (6), suggesting a major contribution to weed suppression. These allelochemicals are water soluble and when imbibed by the germinating weed seeds, hamper their germination and subsequent seedling growth, thus contributing to overall decline in the observed densities [16]. The numerous allelochemicals derived from residues in the field support the contention that allelopathic effects due to a single compound is unlikely and that Sorghum species are inhibitory due to a number of compounds, including cyanogenic glycosides, tannins, flavonoids, quinones, and phenolic acids $[16,18]$. The increases in soil phenolic $\mathrm{C}$ in sorghum residue amended soils have also been observed for other allelopathic crops that achieved concentrations sufficient to decrease growth of target weeds [13].

The relationship between weed densities established in residue treatments and soil phenolic $\mathrm{C}$ in the tillage treatments was moderate but highly significant $(\mathrm{p}<0.001)$ for grass and total weeds (Table 5). No correlation existed for broadleaf weeds, which was likely due to their rather minor proportion of total weed community, especially in 2001. The similar correlations for both tillage systems suggest little difference in affecting soil phenolic $\mathrm{C}$ content and subsequent allelopathic activity. Previous research report variable effects of tillage indicating that sorghum residues either incorporated into soil or allowed to remain on the soil surface both reduce incidence and growth of numerous grass and broadleaf weeds [7]. Few differences in phenolic acid release from rye biomass residues were observed between tilled and no-tilled treatments [17]. In other studies, greater weed suppression is generally observed with reduced tillage relative to no tillage yet residues are generally not expected to reduce weed density in conventional tillage due to residue incorporation versus concentration on the soil surface as for no-tillage [7]. Phenolic concentrations may be elevated in soils after incorporation by tillage and result in quicker contact and effect on weeds in the seedbank $[13,15]$. However, if crop residues contain allelochemicals released during leaching or decomposition, then suppression of weed germination and growth can occur [19]. The latter case seems to apply to our study in which both allelochemical release mechanisms acted similarly in the two tillage systems.

Table 5. Pearson correlation coefficients for the relationship between soil phenolic $C$ content from sorghum residues and weed densities under two tillage regimes during 2000 to 2001.

\begin{tabular}{lll}
\hline \multirow{2}{*}{ Weed densities } & \multicolumn{2}{l}{ Soil phenolic C } \\
\cline { 2 - 3 } & Till & No-till \\
\hline Grass & $-0.543^{*}$ & $-0.564^{*}$ \\
Broadleaf & -0.048 & 0.058 \\
Total & $-0532^{*}$ & $-0.561^{*}$ \\
\hline
\end{tabular}

*Significant at 0.001 probability level

\section{Conclusions}

Sorghum residues expressed inhibitory activity but weed control in the field was affected by interactions with environmental factors, seedbank ecology and tillage leading to weed control that appeared less effective than using herbicides. We report one of the few studies [17] to document allelopathic effects of phenolics in situ and may be the first to evaluate these allelochemicals associated with sorghum residues on weed suppression in the field. This supports the contention that allelopathic research needs to focus on in-field studies where interactions of allelopathic factors with multiple biotic and abiotic variables can be examined for practical application $[17,20]$. A major finding arising from conducting this study in the field is the influence of environmental factors on allelopathic crops, allelochemical fates and the ability to suppress weeds. Einhellig [18] noted a better understanding of the complexity of environment $\mathrm{x}$ allelopathy $\mathrm{x}$ weed growth interactions is needed to obtain consistent field responses with sustainable approaches to crop production.

Weed seedbanks affected by environmental conditions led to different weed densities subjected to suppression by residues in each year. Tillage type had variable effects on weed suppression, similar to previous reports $[7,13,15,17$, 19]. Differential allelopathy was identified among the sorghum hybrids evaluated. Because allelopathic potential of crop cultivars is controlled genetically, improved selection may be used for increased production and release of allelochemicals to control weeds inexpensively, easily, and environmentally friendly [11]. Allelopathic crops in rotation add allelochemicals in soil to suppress weeds in subsequent crops of the rotation. Growing allelopathic crops for weed suppression needs intentional planning to fit into existing cropping patterns. Our results also provide a basis for 
developing novel biological herbicides with little environmental impact. Phenolic acids in the sorghum residues with demonstrated high herbicidal activity include vanillic acid, p-coumaric acid and p-hydroxybenzoate $[6,18]$ could be combined to cause multiple inhibitory effects on target weeds providing an attractive, sustainable weed management option $[7,18]$.

Cropping patterns are primarily determined by agroclimatic conditions and economic benefits of growing a crop, which makes it difficult to introduce allelopathic crops in rotations. However, allelopathic, non-genetically engineered crops may become more reliable because the development of glyphosate-resistant weeds has resulted in increased herbicide applied per hectare, for example, by $25 \%$ in soybean [Glycine $\max ($ L.) Merr.] alone [21]. Allelopathy approaches such as incorporating allelochemical-laden residues may be an additional approach to deplete herbicide-resistant weed components of the soil seedbank [22]. Furthermore, combinations of sorghum residues amended with low rates of herbicide have shown weed suppression similar to control provided by herbicide label rates, without compromising crop yield while reducing herbicide inputs $[15,18]$ However, soil type, environment, growth stages of the allelopathic crop and weed, plant variety traits and cultural practices complicate the use of allelopathy in weed control and benefits gained from this potential environmentally friendly weed control practice [11]. Management will be required to successfully integrate allelopathic crops into sustainable crop production.

\section{Acknowledgements}

This paper is dedicated to our respected colleague, the late Dr. Moncef Ben-Hammouda, who diligently conducted research on sorghum allelopathy in wheat rotations at the University of Missouri in the 1990's and continued allelopathy research with wheat and barley during his academic career at École Supérieure d' Agriculture du Kef in Tunisia. His contributions benefit our understanding of allelopathy and help improve grain production for world food security.

\section{References}

[1] Aldrich, R. J. and R. J. Kremer. 1997. Principles in Weed Management, $2^{\text {nd }}$ edition. Iowa State University Press, Ames, Iowa, USA.

[2] Weston, L. A., I. S. Alsaadawi and S. R. Baerson. 2013. Sorghum allelopathy - from ecosystem to molecule. Journal of Chemical Ecology 39, 142-153.

[3] Einhellig, F. A. and J. A. Rasmussen. 1989. Prior cropping with grain sorghum inhibits weeds. Journal of Chemical Ecology 15, 951-960.

[4] Cheema, Z. A. and A. Khaliq. 2000. Use of sorghum allelopathic properties to control weeds in irrigated wheat in semi-arid region of Punjab. Agriculture, Ecosystems and Environment 79, 105-112.
[5] Ben-Hammouda, M., R. J. Kremer and H. C. Minor. 1995a. Phytotoxicity of extracts from sorghum plant components on wheat seedlings. Crop Science 35, 1652-1656.

[6] Ben-Hammouda, M., R. J. Kremer, H. C. Minor and M. Sarwar 1995b. A chemical basis for differential allelopathic potential of sorghum hybrids on wheat. Journal of Chemical Ecology 21, 775-786.

[7] Batish, D. R., H. P. Singh, R. K. Kohli and G. P. Dawra. 2006. "Potential of allelopathy and allelochemicals for weed management," in Handbook of Sustainable Weed Management, H. P. Singh, D. R. Batish and R. K. Kohli, Eds. Binghamton, NY: Food Products Press, pp. 209-256.

[8] Li, L.-L., T.-L. Li, G.-C. Zhang, E.-P. Zhang, J. Zhang and Z.-C. Wu. 2013. Degradation patterns of phenolic acids in soil. Allelopathic Journal 31, 181-188.

[9] Einhellig, F. A. 1986. "Mechanisms and modes of action of allelochemicals," in The Science of Allelopathy, A. R. Putnam and C.-S. Tang, Eds. New York: John Wiley \& Sons, pp. 171-188.

[10] Wu, H., J. Pratley, D. Lemerle and T. Haig. 1999. Crop cultivars with allelopathic capability. Weed Research 39, 171-180.

[11] Abbas, T., Z. A. Zahir, M. Naveed and R. J. Kremer. 2018. Limitations of existing weed control practices necessitate development of alternative techniques based on biological approaches. Advances in Agronomy 147, 239-280.

[12] Osipitan, O. A., J. A. Dille, Y. Assefa, E. Radicetti, A. Ayeni and S. Z. Knezevic. 2019. Impact of cover crop management on level of weed suppression: a meta-analysis. Crop Science 59, 833-842.

[13] Ohno, T., K. Doolan, L. M. Zibilske, M. Liebman, E. R. Gallandt and C. Berube. 2002. Phytotoxic effects of red clover amended soils on wild mustard seedling growth. Agriculture, Ecosystems \& Environment 78, 187-192.

[14] Forcella, F., R. G. Wilson, J. Dekker, R. J. Kremer, J. Cardina, R. L. Anderson, D. Alm, K. A. Renner, R. G. Harvey, S. Clay and D. D. Buhler. 1997. Weed seed bank emergence across the Corn Belt. Weed Science 45, 67-76.

[15] Lahmod, N. R. and I. S. Alsaadawi. 2014. Weed control in wheat using sorghum residues and less herbicide. Allelopathy Journal 34, 277-286.

[16] Sene, M., T. Dore and F. Pellesier. 2000. Effect of phenolic acids in soil under and between rows of a prior sorghum (Sorghum bicolor) crop on germination, emergence and seedling growth of peanut (Arachis hypogea). Journal of Chemical Ecology 26, 625-637.

[17] Otte, B. A., C. P. Rice, B. W. Davis, H. H. Schomberg, S. B. Mirsky and K. L. Tully. 2020. Phenolic acids released to soil during cereal rye cover crop decomposition. Chemoecology 30 , $25-34$.

[18] Einhellig, F. A. 1996. Interactions involving allelopathy in cropping systems. Agronomy Journal 88, 886-893.

[19] Tabaglio, V., A. Marocco and M. Schulz. 2013. Allelopathic cover crop of rye for integrated weed control in sustainable agro-ecosystems. Italian Journal of Agronomy 8, 35-40. doi: 10.4081/ija.2013.e5. 
[20] Blum, U., S. R. Shafer and M. E. Lehman. 1999. Evidence for inhibitory allelopathic interactions involving phenolic acids in field soils: concepts vs. an experimental model. Critical Reviews in Plant Science 18, 673-693. https://doi.org/10.1080/07352689991309441

[21] Beckie, H. J. and L. M. Hall. 2014. Genetically-modified herbicide-resistant (GMHR) crops a two-edged sword? An Americas perspective on development and effect on weed management. Crop Protection 66, 40-45.
[22] Sosnoskie, L. M., T. M. Webster and A. S. Culpepper. 2013. Glyphosate resistance does not affect palmer amaranth (Amaranthus palmeri) seedbank longevity. Weed Science 61, 283-288. 